\title{
Introduction: Career Construction Theory and Life Writing
}

In the introduction to a 2017 special issue (14.3) of this journal devoted to the 'limits' of life writing, David McCooey suggested that an increasing degree of theoretical investigation into the properties of the autobiographical genre over the past two decades resulted in the term autobiography gradually being superseded by the more flexible one, life writing. This process was characterised, he argued, by an expansion of the object of study, becoming less strongly focused on literary texts and genres and more critically interested in other forms of life writing more generally: testimony, autoethnography, the representation of the self in digital media including social media, and so on. In a sense, the current volume about Career Construction Theory and Life Writing can be seen as an extension of that process.

Career construction theory emerged during the final decades of the twentieth century, which was a period when fundamental changes to people's patterns of work and life had caused large numbers of people to seek new forms of vocational guidance to equip them to negotiate those changes. Whereas previous forms of professional guidance had employed aptitude tests, statistical profiling and other forms of quantitative analysis, career construction takes a far more qualitative approach to employment counselling. By encouraging clients to see their careers as stories of which they are both the metaphorical authors and the main protagonists, career construction counsellors enable them to envisage the next chapter in those stories. Periods of troubling change or uncertainty, when people do not know what to do next in their lives, are thus treated as experiences akin to 'writer's block', experiences which can be overcome first by imagining new character arcs, then by narrating them and finally by performing them. Larry Cochran (1997) defines career construction theory as a narrative based practice 
because it is all about elucidating life stories and using them as resources to endow vocational decisions with meaning and value to the individual in question. Mark Savickas (2011) emphasises that creating potential new career trajectories in narrative relies on a process of co-construction between the vocational counsellor and the advisee, with the former eliciting a series of components for the gradually emerging narrative from the latter through conversation and dialogue.

Beyond the value and significance they generate for each person concerned, the kinds of career narrative that emerge from career counselling have not received much broader critical or theoretical attention. An implicit argument to be made throughout Career Construction Theory and Life Writing is that to direct new levels of critical interest towards career narratives accords with the process identified by McCooey in 2017 whereby scholars and readers of life writing have increasingly supplemented an interest in creative and literary material with a corresponding and previously underexplored examination of non-fictional genres, texts and narratives. To open up career construction theory to detailed theoretical investigation is thus to open up the previously untapped but potentially fertile potential of that body of work to inform how we think both about career narratives and about the multiplicity of varieties of life writing more generally.

As I show in the first paper, 'From Writer's Block to Extended Plot: career construction theory and lives in writing' there are numerous reasons why career narratives might appropriately be treated as new forms of life writing; and why doing so might enable new critical forms of knowledge and understanding beyond those of autobiography or more traditionally literary genres. The most significant of these is that career 
construction is a narrative practice that creates new forms of life and career narratives. These are based on nonfictional components such as memory and autobiographical reasoning, but at the same time they are specifically created to enable changed behaviours and the taking of sometimes courageous vocational decisions so that they should properly be seen as forms of creativity.

To put it another way, the narratives co-authored by career construction counsellors and their clients might not contain the aesthetic properties traditionally associated with great art; and might not have any audience or readership beyond the individual in question. But this does not prevent them from being seen as fully creative forms of writing and expression, if only because they are written in the specific expectation of enabling the individual in question to see his or her life from an imagined vantage point outside it, thereby attaining a degree of critical distance and new forms of selfknowledge and understanding. In other words, although career narratives are coauthored by the counsellor and the person whose career they narrate, they are also primarily read by that same person who is therefore simultaneously author and audience of the narrative in question. But the purpose of constructing career trajectories in narrative is to evaluate past behaviours as a guide for future decisions and actions. This means that the individual in question not only creates and reads the career narrative, but also acts upon it: they are author, reader and protagonist in their own career stories. This means that career construction theory provides a means of articulating the tensions that arise when individuals people negotiate the transition between one life chapter and another, which often means moving between one stage in their career and the next or between one role and another. 
Career construction treats a career as a particular form of artefact that, though intangible in a physical sense, nevertheless has certain material properties which have to be created in order to exist and which can therefore be analysed from a materialist perspective. The main component through which this construction occurs is language, and above all narrative. The entire field of career construction theory mobilises a conception of authorship and related metaphors which when taken together make it possible to think about career narratives as forms of life writing, perhaps for the first time. In doing so, our understanding of career narratives, and of the material dimensions of authorship more generally, are mutually transformed. Adding career construction theory to an investigation of life writing expands both fields and provides a new way of thinking about authorial careers that is different from both analytical exegesis of given texts and from traditional biographical criticism.

This does not mean, however, that career construction cannot be used to provide a lens through which textual analysis might be carried out. On the contrary, one of the potential benefits to be derived from bringing it into the domain of life writing is to provide a fresh means of exploring how work, working lives, vocations and careers have been represented in forms of writing, both fictional and nonfictional. Thus Jeffrey Clapp’s paper ‘Undisguised Alter Ego: Mary McCarthy’s Autofictional Career’ presents two principal arguments: first that the career of the author should be seen as an object of critical analysis in ways that are distinct from more traditional textual objects; and second, that representations of that career in texts produced at different moments in it tell us something about how the career is constructed and elaborated at different times. This means that Clapp's chapter serves as a corrective to approaches to McCarthy's career that have tended to treat considerations of career construction either in a purely 
abstract way or as a straightforward extension of the self-reflexivity for which she is known. What emerges instead is a dynamic account of the interrelationship between the material components of an authorial career and the writing produced at diverse stages in it, which both reflects and has an impact upon the construction of that career in a material, as opposed to purely abstract, way.

Clapp treats Mary McCarthy's career as a potential object of analysis in its own right, as distinct from the textual objects produced during the course of that career. In doing so, he implicitly suggests that this approach to careers as linguistic constructs is potentially paradigmatic for authorial careers more generally. The third paper, 'Academic Career Construction: Personnel Documents as Personal Documents' by Lisa Ortiz-Vilarelle, shares Clapp's interest in the transition between different career stages but with a different focus. In an exercise of autoethnography, Ortiz-Vilarelle reflects on her own experience of having recently applied for promotion within an academic institution, treating the application essays and accompanying supplementary materials as forms of life writing that have so far failed to be recognised as such. Whilst it is clear that these are not forms of life writing of a fictional or imaginative (or in that sense creative) nature, they nevertheless have a direct bearing on the elaboration of the physical career of the individual in question and are therefore powerful and affective forms of narrative for a specific and limited readership. In other words, although promotion application essays do not necessarily have wide readerships in the way that novels and autobiographies often do, and although they are not generally seen as instances of creative work at all, to treat them as meaningful forms of life writing accords with the historical evolution of the field discusses above, whereby the once-dominant literary 
genres have become somewhat less privileged over time with the result that other forms have received greater theoretical attention.

In Ortiz-Vilarelle's case, what emerges is a strong sense of the dilemmas felt regarding how much of the author's personality, emotions and experiences can and cannot be included in a promotion transcript. To include too much is to lay oneself open to the charge of over-sharing and to risk making colleagues feel uncomfortable, thereby endangering the whole promotion process. Yet to include too little of one's own life circumstances somehow feels untrue or even deceitful to the writer's sense of her own self and aspirations. This dilemma creates a double bind which Ortiz-Vilarelle points out has been particularly problematic for female and ethnic minority academics, whose complex life circumstances frequently have an impact on their working lives that cannot simply be ignored yet who might be accused of trespassing onto terrain not directly relevant to their work if they decide to discuss such circumstances in the narratives they submit to promotion committees.

Implicit in Ortiz-Vilarelle's analysis is the suggestion that considering application essays as forms of life writing is not an end in its own right, as if in fulfilment of some kind of ludic game. The purpose of such classification is to explore what new forms of knowledge and what new critical perspectives are generated by doing so. Considering the situatedness of female and ethnic minority academics and the different kinds of life experience they bring to bear on the academic promotion process raises tacit questions about inclusivity and representativity which are in the last instance questions about equality of opportunity in a participatory democracy. That is to say, treating application materials as forms of life writing is important because it sheds light on a process that 
would otherwise seem less transparent, and in doing so opens the process itself up to critical interrogation and potential change. This potential is important because the question ultimately being asked is: which academics get promoted to higher roles and why? A process that indirectly hinders the opportunities for accession to leadership roles for women or ethnic minorities (or both) is therefore likely to allow a repetition of existing structures of inequality across generations. Bringing career construction theory to bear on those existing structures thus creates a newly critical vantage point from which to advocate change.

Although Ortiz-Vilarelle does not quite go as far as to say this herself, the question of who gets promoted to higher roles in academic institutions also touches on a wider question which is: how far can universities contribute to developing the critical consciousness of their students? Implicit in her analysis was the suggestion that where senior positions are occupied exclusively by white men, this creates inequality not only among faculty members but also in the last instance creates an unrepresentative worldview among the students. Teaching critical thinking in higher education is more explicitly the subject of the Karen Fowler-Watt's paper, 'The auto/biographical journalist and stories of lived experience,' which examines the case studies of two journalists who have moved into journalism education. Fowler-Watt argues that journalists use narratives of lived experience both to help them manage the transition into a new career role (which is the core component of career construction theories) and as educational tools. Discussing the relationship and sometimes difficult distinction between personal and professional identities, she adumbrates the idea of 'auto/biographical journalism' as a means of scrutinising the role of the self in making two distinct but related vocational choices: that of journalist; and that of educator. As a 
former BBC journalist and current journalism educator herself, Fowler-Watt adds her own voice to those of the two practitioners whose careers form the principal case studies of the paper, so that a feeling of dialogue between not two, but three different voices gradually unfolds. This feeling of gradual emergence is strengthened by the use she makes of Norman Denzin's 1989 concept of cumulative epiphanies, which are defined not merely as life changing moments or problematic experiences, but emotional responses and reactions to those experiences over time.

Complex questions about the personal stake held by journalists in the stories they report are explored in different ways in Michael Humphrey and Lorie Humphrey's paper, 'Career Construction in Volatile Settings.' Drawing on Mark Savickas's idea in Career Counseling that setting is an important consideration for identifying and fulfilling vocational aspirations, Humphrey and Humphrey argue that Twitter in effect provides a new kind of setting in which the profession of journalism occurs. Beginning with a discussion of the apparent decline in the profession brought on by social media, they observe that journalists have started to use social media to fight back: using Twitter to tell personal micro narratives, which appear to violate the journalist principle of impersonality and which make the persona of the journalist much more prominent in the story. As a setting for the practice of journalism, however, it becomes apparent that Twitter is a site where ideas about journalistic insight and integrity are contested. Their analysis of 12,550 tweets about journalism (rather than by journalists) reveals six recurring themes, each of which frame various assaults on journalistic integrity by calling into question the objectivity and even the honesty of journalists. Postings of this nature attempt to foreclose on public debates of a highly politicised nature such as the murder of Washington Post columnist Jamal Khashoggi by Saudi assassins in its Turkish 
embassy in October 2018, and President Trump's reticence to criticise the Saudi regime whom he saw as key allies in the Middle East. As another example, Humphrey and Humphrey focus on the Twitter presence of Elizabeth Hernandez, a reporter for the Denver Post, who used her social media presence to criticise the practices of the hedge fund which owned the Post, Alden Global Capital.

As Humphrey and Humphrey show, postings of this kind rapidly become semantic battlegrounds over the politics of Trump's America more generally, where what is really at stake is the capacity for writers to speak truth to power and hence generate critical narratives that contest the truth claims of the governing administration. Through the example of Elizabeth Hernandez, they show that although the growth of social media has wrought significant changes on the journalistic profession, it has also brought with it certain opportunities for public resistance. In fact, one of the overarching questions that concerns Humphrey and Humphrey in applying career construction theory to their analysis of these developments is: How can it provide a broad career narrative in a profession that is changing all the time? Their answer to this is to suggest that career narratives have actively to be constructed rather than being simply experienced, and that identifying appropriate settings for the unfolding of that career is one of the most effective means of enabling this construction to take place. Treating Twitter as a specific locus for career construction narratives more broadly makes it possible for journalists who do so to develop qualities of resilience and adaptability, equipping them for subsequent changes in their professional sphere rather than experiencing such changes in a passive way. 
The development of resilience through narrative is more explicitly the subject of the final two papers. In 'Narrative Medicine in China: How Doctors Write to Understand the Profession', Rong Huang analyses how physicians' self-reflective writings reshape their outlook upon the ideas of illness, their relationships with others involved in the medical process, and their identity as doctors for the larger community. In emphasising the cultural specificity of the Chinese context and its tradition of Confucianism, Huang expounds an alternative genealogy for the development of narrative approaches to medical practice, which have often been rooted exclusively or almost exclusively in the West. She argues that the act of writing about oneself helps to humanise medical science, which is important for medical practitioners partly because it strengthens the bond between the individual and his or her community and even more because doing so combines behaviours taken from both the sciences and the humanities and thereby positions the patient as an active agent in the narrative rather than its mere recipient, or worse still, victim. Larry Cochran (1997) and Kobus Maree (2013) have both demonstrated that creating opportunities for individuals to transform patient or victim scripts into actor or agent ones is one of the most important properties of career construction narratives.

This emphasis on the refusal of a victim or patient mentality through creative forms of self-expression is even more explicitly the case in Reinekke Lengelle's paper 'Writing the Self and Bereavement: dialogical means and markers of moving through grief.' Using the methodology of autoethnography, Lengelle writes and reflects on her spouse's illness and death. She takes as her starting point the fact that expressive writing can be a beneficial response to grief or bereavement is well established within existing theoretical literature, but that there is little or no definition of what constitutes a 
beneficial narrative. Seeking to fill this theoretical lacuna, at least in her own case, she engages in an exercise in expressive writing inspired by Hubert Hermans's dialogical self theory (2010). This leads her to conceptualise aspects of her own self and troubling aspects of her relationship with her now-deceased spouse as different speakers in a scripted dialogue. Taking this authorial stance both entails adopting a perspective on her experience that is located somewhere outside herself and necessitates her confronting one of the most difficult aspects of grief: the fact that there are now things that can never be said to the lost partner, actions that will never be completed, and other forms of unfinished business.

Although to suggest that writing the expressive dialogue provides any form of closure would be to reduce the experience to the banal language of soap opera, doing so enables Lengelle to extrapolate markers that might indicate elements of a potentially beneficial narrative of the self arising out of it. She identifies these markers by drawing on Hermans's concept of different I-positions and equates one's transition between them with stages in the construction of an empowering narrative of the self. Initial I-positions are inert and tightly bounded and may imply a feeling of entrapment. A beneficial narrative of the self emerges out of the dialogue through the gradual construction and adoption of more fluid I-positions, which she follows Hermans in referring to as metaand promoter-positions, where the self is seen as being more pluralistic, thereby allowing a lesser feeling of inertia. Lengelle argues that the main benefit for the bereaved to derive from expressive writing is that the experience of discovering that such positions are available from within can expand their personal agency in moments when a problem seems urgent and unresolvable. Since the goal of this kind of writing is to achieve a transformation in the self through writing, she concludes by cautiously 
suggesting that writing dialogically can help us create opportunities for personal development out of experiences of loss and pain.

Writing in Counselling for Career Construction - Connecting Life Themes to Construct Life Portraits: Turning Pain into Hope (2013) Kobus Maree notes: 'We assume that clients' stories start only when things go wrong. How else?' (p.63). Such an element is in fact a recurring theme in the existing theoretical literature on the uses of narrative in forms of career construction. For this reason, Lengelle's focus on turning suffering into empowerment brings this volume full circle. Not only has it been argued - both by Clapp and Ortiz-Vilarelle - that authorial careers are specific forms of object which are amenable to material analysis by literary scholars in addition to analysing the particular textual objects that once dominated the field; but also that the narrative method of constructing career trajectories is applicable to all careers, not merely those of 'authors.' In this sense, theories of career narratives have the potential to revivify the field of authorial research by providing a new way of thinking about authorship and at the same time, authorial careers are paradigmatic of what career construction approaches tell us about working lives more generally. In settings as diverse as academia, journalism or medicine and addressing life experiences from career changes to bereavement, the papers collected here adumbrate the construction of new life stages and life roles by telling new kinds of stories about the self. The construction of career trajectories in narrative at times equips people to develop qualities of resilience in the face of a changing professional landscape; at times enables more effective relationships between individuals and the diverse communities of which they are part; and at times bears on larger abstract questions of truth, justice and equality. This perhaps is most of all why career construction theory deserves to be seen as a valuable form of life writing, 
because in the changing world of the twenty-first century those abstract quantities themselves have increasingly needed to be re-interrogated and approached in new ways.

\section{References}

Cochran, Larry. Career Counseling: A Narrative Approach. Thousand Oaks, CA: Sage, 1997.

Denzin, Norman K. 1989. Interpretive Biography. Thousand Oaks, CA: Sage.

Hermans, Hubert, and Agnieszka Hermans-Konopka, eds. 2010. Dialogical Self Theory:

Positioning and Counter-Positioning in a Globalizing Society. Cambridge: Cambridge University Press.

Maree, Jakobus. Counselling for Career Construction. Connecting Life Themes to Construct Life Portraits: Turning Pain into Hope. Rotterdam: Sense, 2013.

McCooey, David and Maria Takolander. 2017. “Editorial: The Limits of Life Writing.” Life Writing 14 (3): 277-280.

Savickas, Mark. 2011. Career Counseling. Washington, D.C.: American Psychological Association (Theories of Psychotherapy). 